\title{
Tingkat Smartphone Addiction pada Penduduk di Kota Banda Aceh
}

\author{
Rita Fathya, Kartika Sari, Marty Mawarpury, Afriani \\ Program Studi Psikologi, Fakultas Kedokteran \\ Universitas Syiah Kuala, Banda Aceh, Indonesia \\ email: ritafathiya@gmail.com,
}

\section{Artikel INFO}

Diterima:21 Mei 2020

Direvisi :19 Sep2020

Disetujui: 11 Nov 2020

DOI:

http://dx.doi.org/10.24014/ jp.v14i2.9794

\section{Abstrak}

\begin{abstract}
Penggunaan smartphone menjadi kebutuhan utama saat ini, namun penggunaan yang berlebihan dapat berdampak buruk salah satunya smartphone addiction. Smartphone addiction adalah suatu bentuk keterikatan terhadap smartphone yang memungkinkan terjadinya masalah sosial seperti menarik diri dan kesulitan dalam melaksanakan aktivitas sehari-hari. Penelitian ini bertujuan untuk mendeteksi tingkat masalah dan faktor demografi yang berkontribusi terjadinya smartphone addiction pada penduduk di Banda Aceh. Menggunakan desain kuantitatif dengan metode survei, responden penelitian ini berjumlah 500 orang, dengan teknik pengumpulan sampel menggunakan unrestricted self-selected surveys. Pengumpulan data penelitian diperoleh menggunakan skala adaptasi Smartphone Addiction Scale Short Version (SAS-SV) yang dikembangkan oleh Kwon, dkk. Berdasarkan hasil penelitian dapat diketahui tingkat smartphone addiction pada penduduk di Kota Banda Aceh tidak jauh berbeda persebarannya, yaitu sebanyak $51.4 \%$ subjek berada pada tingkat smartphone addiction rendah dan $48.6 \%$ subjek berada pada tingkat smartphone addiction tinggi. Hasil uji Chi Square menunjukkan terdapat beberapa variabel demografi yang berkontribusi terhadap tingkat smartphone addiction $(p<0.05)$ yaitu usia, pendidikan terakhir, pekerjaan, total waktu penggunaan smartphone perhari, dan rutinitas memeriksa smartphone perhari.
\end{abstract}

Kata kunci: Penduduk Banda Aceh; Smartphone Addiction; Tingkat;

\section{Level of Smartphone Addiction on Banda Aceh Society}

\begin{abstract}
The use of smartphones is a basic necessity at this time, but excessive use can lead a bad impact, one of them is smartphones addiction. Smartphone addiction is a form of attachment to smartphones that allows social problems such as withdrawal and daily disturbance. This study aims to determine the problem level and demographic factors that contribute the smartphone addiction on society in Banda Aceh. Using a quantitative design with a survey method, the respondents of this study were 500 people, with sample collection techniques using unrestricted self-selected surveys. Research data collection was obtained using adaptation the Smartphone Addiction Scale Short Version (SAS-SV) by Kwon, dkk. Based on the results of the study it can be seen that the level of smartphone addiction in the population on Banda Aceh society not much different, there are $51.4 \%$ subjects with low smartphone addiction levels and $48.6 \%$ subjects with high smartphone addiction levels. Chi Square test results showed that there are several demographic variables that contributed to smartphone addiction level $(p<0.05)$, age, education level, occupation, duration of smartphone use on single day, and frequency of smartphone check on single day.
\end{abstract}

Keywords: Banda Aceh society; Level; Smartphone Addiction;

\section{Pendahuluan}

Salah satu kecanggihan teknologi adalah hadirnya smartphone untuk memenuhi segala kebutuhan yang dapat menggantikan handphone dan komputer (Samaha \& Hawi, 2016). Saat ini smartphone telah melalui banyak perubahan dan menjadi semakin canggih dengan tersedianya beragam fasilitas dan fitur yang dapat memudahkan penggunanya sehingga membuat penggunanya semakin meningkat (Wardani, 2016; Wijanarko, 2014).

Penggunaan smartphone didorong oleh tiga hal yaitu mengakses internet untuk mencari informasi, untuk terhubung dengan teman, dan sebagai sarana hiburan (Panji, 
2014). Selain beberapa kemudahan yang diberikan terdapat juga masalah dan kerugian terkait penggunaan smartphone yaitu penggunaan smartphone yang berlebihan dapat menyebabkan terjadinya smartphone addiction atau kecanduan terhadap smartphone (Kibona \& Mgaya, 2015; Ithnain, Ghazali \& Jaafar, 2018). Smartphone addiction adalah suatu bentuk keterikatan atau kecanduan terhadap smartphone yang memungkinkan terjadinya masalah sosial seperti menarik diri dan kesulitan dalam melaksanakan aktivitas sehari-hari atau sebagai gangguan kontrol impuls pada diri seseorang (Kwon dkk., 2013a).

Masalah smartphone addiction merupakan masalah yang terjadi di berbagai tempat termasuk di Asia. Penelitian yang dilakukan oleh Soni, Upadhyay, dan Jain (2017) pada 587 siswa SMA di India menunjukkan hasil sebanyak $53.62 \%$ subjek penelitian mengalami smartphone addiction tinggi dan sebanyak $33.3 \%$ mengalami smartphone addiction rendah. Di Korea penelitian terkait penggunaan smartphone jugapernah dilakukan oleh Cha dan Seo(2018) pada 1824 siswa SMA, menunjukkan hasil sebanyak $30.9 \%$ subjek penelitian mengalami smartphone addiction tinggi dengan rata-rata penggunaan smartphone selama 6 jam per hari. Penelitian ini juga menunjukkan faktor prediktif yang menyebabkan smartphone addiction yaitu durasi penggunaan jejaring sosial yang tinggi, dan bermain game yang berlebihan. Di Asia Tenggara penelitian terkait smartphone addiction juga pernah dilakukan oleh Ithnain, dkk (2018) pada 396 mahasiswa di Malaysia menunjukkan hasil hampir setengah dari subjek penelitian $47.7 \%$ mengalami smartphone addiction tinggi. Penelitian lainnya dilakukan di Chiang Mai, Thailand pada 800 mahasiswa menunjukkan hasil sebanyak $45.8 \%$ dari subjek penelitian mengalami smartphone addiction yang mengakibatkan rendahnya kesejahteraan psikologis (Tangmunkongvorakul dkk., 2019).
Masalah smartphone addiction juga ditemukan di Indonesia, hal tersebut dapat terlihat pada penelitian yang dilakukan oleh Tarlemba, Asrifuddin, dan Langi (2018) pada 173 siswa SMA di Manado menunjukkan hasil sebanyak $56.1 \%$ subjek penelitian mengalami smartphone addiction. Penelitian lainnya juga dilakukan pada 321 mahasiswa di Makassar untuk mengetahui tingkat dan tujuan penggunaan smartphone, menunjukkan hasil sebanyak $81.3 \%$ subjek penelitian mengalami smartphone addiction dengan penggunaan rata-rata 6 jam perhari dan tujuan penggunaan smartphone terbanyak adalah untuk mengakses media sosial (Lukman, 2018).

Fenomena smartphone addiction juga terdapat di Banda Aceh, beberapa penelitian sebelumnya mengenai smartphone addiction pernah dilakukan dilakukan oleh Mulyana dan Afriani (2017) pada remaja SMA di Banda Aceh yang menunjukkan bahwa sebanyak $32,5 \%$ dari 336 sampel penelitian berada pada tingkat resiko tinggi smartphone addiction, sementara penelitian lainnya yang dilakukan Rossa (2016) pada mahasiswa di Fakultas Keperawatan Universitas Syiah Kuala menunjukkan hasil sebanyak 26,4\% dari 89 sampel penelitian berada pada tingkat resiko tinggi smartphone addiction.

Bentuk dari smartphone addiction berbeda dengan internet addiction, internet addiction seperti kecanduan terhadap games, dan chatting, sedangkan smartphone addiction adalah kecanduan terhadap aplikasi dan fitur yang tersedia di smartphone seperti pemutar musik, kamera, media sosial, bahkan aplikasi edit foto (Kim, 2013). Studi menunjukkan individu yang mengalami smartphone addiction menganggap smartphone merupakan bagian penting dari kehidupannya dan merasa kosong tanpa smartphone. Individu yang mengalami smartphone addiction menunjukkan perilaku seperti merasa sulit berkonsentrasi ketika sedang 
belajar atau bekerja, lupa mengerjakan pekerjaan yang telah direncanakan, selalu membawa pengisi daya kemanapun, merasa hubungan yang lebih intim dengan temanteman yang ada di aplikasi smartphone, merasa gembira dan dapat menghilangkan stres ketika menggunakan smartphone, dan merasa hampa tanpa smartphone (Kwon dkk., 2013a).

Penelitian yang berkaitan dengan smartphone addiction lainnya juga pernah dilakukan oleh Lurhmann dari Universitas Stanford pada tahun 2010. Hasil penelitian tersebut menemukan bahwa pada 200 subjek yang menggunakan smartphone, seluruh subjek sangat aktif dalam menggunakan smartphone-nya, dan banyak subjek yang mengandalkan smartphone sebagai bagian dari gaya hidupnya. Secara keseluruhan, $10 \%$ dari subjek penelitian sepenuhnya kecanduan smartphone, $34 \%$ pada peringkat hampir kecanduan, dan 6\% mengatakan tidak kecanduan sama sekali. Selanjutnya, $75 \%$ mengaku tidur dengan membawa smartphone, dan 69\% melaporkan bahwa lebih baik melupakan dompet daripada harus meninggalkan smartphone-nya. Meskipun tingkat kecanduan berat tidak terlalu tinggi sebagai efek samping dari penggunaan smartphone, namun $41 \%$ dari subjek mengatakan apabila mereka kehilangan smartphone hal tersebut merupakan suatu peristiwa yang tidak menyenangkan, sedangkan $22 \%$ dari subjek mengatakan apabila mereka kehilangan smartphone hal tersebut lebih berbahaya dari apapun (Hope, 2010).

Smartphone addiction secara negatif mempengaruhi kehidupan sehari-hari individu baik dari segi sosial, fisik, maupun psikologis. Individu yang mengalami smartphone addiction lebih menyukai interaksi melalui media sosial dibandingkan dengan harus bertemu secara langsung (Bian \& Leung, 2014), merasa cepat lelah, sakit kepala dan gangguan fisik seperti sakit pada persendian (Hernanda, 2017), dan dapat menyebabkan seseorang menjadi stres, cemas, dan depresi (Boumosleh \& Jaalouk, 2017). Hal tersebut dapat terlihat pada penelitian yang dilakukan oleh Suwannahong (2018) pada 400 mahasiswa di Thailand, menemukan bahwa lamanya waktu penggunaan smartphone dapat berpengaruh terhadap kesehatan mata dan juga kesehatan mental. Durasi penggunaan smartphone yang berlebihan terbukti memiliki hubungan positif dengan gejala musculoskeletal yaitu gangguan anggota badan pada leher dan persendian (Kim \& Kim, 2015). Penggunaan smartphone yang dilakukan pada malam hari dapat pula berkaitan dengan gangguan tidur yang buruk, gejala insomnia, dan gejala depresi (Lemola dkk., 2014). Menurut Bhattacharyya (2017) penggunaan smartphone yang berlebihan cenderung menyebabkan iritabilitas, sulit tidur, harga diri rendah, dan masalah psikologis lainnya. Penelitian mengenai smartphone addiction lainnya juga dilakukan oleh Yang, Lin, Huan dan Chang (2018) pada 218 remaja SMP hasil penelitian juga menunjukkan terdapat korelasi positif antara durasi penggunaan smartphone $>3$ jam perhari dapat berkaitan dengan kesehatan fisik dan mental yang buruk pada remaja.

Pada survei yang dilakukan oleh Woodall (2018) dalam Review.org melaporkan masalah smartphone addiction yang dialami oleh 2000 laki-laki dan wanita berusia 18 54 tahun dimana $76,5 \%$ subjek menganggap dirinya kecanduan smartphone, 57,5\% berada pada kecanduan tingkat sedang dan $19 \%$ berada pada tingkat sangat kecanduan. Selanjutnya $54,5 \%$ subjek mengatakan bahwa menggunakan smartphone ketika sedang mengemudi, 91,5\% subjek merasa tidak nyaman jika berpergian tanpa membawa smartphone, dan $62 \%$ subjek mengatakan bahwa memeriksa smartphone hingga 160 kali dalam sehari. Hasil dari survei ini menunjukkan bahwa tidak 
terdapat perbedaan pada cara seseorang menggunakan smartphone meskipun dengan rentang usia yang berbeda.

Permasalahan smartphone addiction tidak hanya terjadi pada rentang usia remaja saja, tetapi juga terjadi pada rentang usia dewasa. Seperti penelitian yang dilakukan kepada 6000 orang tua yang memiliki anak berusia 8-13 tahun. Hasil penelitian menunjukkan sebanyak $52 \%$ orang tua mengaku lebih sering memeriksa ponsel mereka daripada memperhatikan anak-anaknya. Menariknya, sebanyak $28 \%$ dari orang tua menyadari bahwa mereka telah mengajarkan hal yang tidak baik pada anak ketika terus menerus bermain ponsel, akan tetapi mereka juga mengaku tidak tahu bagaimana cara berhenti dari ketergantungan tersebut. Sementara itu, dari pihak anak, sebanyak $54 \%$ mengaku jika orang tua mereka memang lebih sering bermain dengan smartphone. Bahkan, 32\% anak-anak yang menjadi subjek penelitian merasa bahwa orang tua mereka lebih mementingkan smartphone daripada dirinya (Gravelly, 2015).

Menurut Kwon, Kim, Cho, dan Yang (2013b) terdapat 5 aspek dari smartphone addiction, yaitu Daily-life Disturbance yang merupakan gangguan kehidupan seharihari mencakup hilangnya pekerjaan yang sudah direncanakan, mengalami kesulitan konsentrasi di dalam kelas atau saat bekerja, penglihatan menjadi buram, nyeri pada pergelangan tangan dan di belakang leher serta terjadinya gangguan tidur.

Kedua adalah Withdrawal, yaitu rasa tidak sabar, gelisah, dan tidak mampu tanpa smartphone, selalu mengingat smartphone meskipun tidak menggunakannya, tidak pernah berhenti menggunakan smartphone danmenjaditersinggungapabila diganggusaat sedang menggunakan smartphone.Ketiga adalah Cyberspace-oriented relationship, hal ini mencakup pertanyaan mengenai seseorang yang merasa hubungan dengan teman yang dikenalnya melalui smartphone menjadi jauh lebih akrab daripada hubungan dengan teman di kehidupan nyata, mengalami perasaan kehilangan yang tidak terkendali ketika tidak menggunakan smartphone dan selalu memeriksa smartphone.

Keempat adalah Overuse, yaitu penggunaan smartphone yang tidak terkontrol, lebih memilih mencari sesuatu lewat smartphone daripada meminta bantuan orang lain, selalu mempersiapkan alat pengisi daya smartphone, dan dorongan untuk kembali menggunakan smartphone setelah berhenti menggunakannya. Kelima adalah Tolerance, yaitu selalu berusaha untuk mengontrol agar tidak menggunakan smartphone akan tetapi selalu gagal melakukannya.

Terlepas dari pentingnya smartphone dalam kehidupan sehari-hari, ternyata penggunaan smartphone secara tidak terkendali dapat mempengaruhi kehidupan penggunanya. Masalah smartphone addiction merupakan permasalahan umum yang terus menerus meningkat setiap tahunnya. Penggunaan smartphone pada berbagai kalangan usia dan pekerjaan serta tersedianya kemudahan dalam mengakses internet dapat mengarah pada peningkatan penggunaan smartphone yang berdampak mengalami smartphone addiction, yang mana salah satu lokasi yang berpotensi memiliki masalah smartphone addiction adalah Kota Banda Aceh. Kota Banda Aceh merupakan pusat kota yang menyediakan jaringan internet yang bagus, sehingga membuat penggunaan smartphone yang berbasis internet meningkat di Kota Banda Aceh. Berdasarkan survei yang dilakukan Asosiasi Penyelenggara Jasa Internet Indonesia (2012) menunjukkan bahwa Kota Banda Aceh merupakan daerah penetrasi pengguna internet yang cukup tinggi dibandingkan dengan kota-kota lain di Sumatera dengan persentase sebesar $36.1 \%$, sehingga dengan tersedianya kemudahan mengakses internet ini dapat 
menyebabkan seseorang bertambah lama dalam penggunaan smartphone yang mana hal ini dapat meningkatkan kemungkinan seseorang mengalami smartphone addiction.

Berdasarkan uraian yang telah peneliti paparkan, peneliti tertarik untuk meneliti mengenai smartphone addiction pada penduduk di Kota Banda Aceh. Tujuan dari penelitian ini adalah untuk mendeteksi tingkat masalah dan faktor demografi yang berkontribusi terjadinya smartphone addiction pada penduduk di Kota Banda Aceh.

\section{Metode}

\section{Subjek}

Penelitian ini melibatkan 500 subjek dengan karakteristik penduduk Kota Banda Aceh, laki-laki dan perempuan dengan rentang usia 15-54 tahun, dan menggunakan smartphone. Teknik pengambilan sampel yang digunakan adalah unrestricted self selected survey, yaitu teknik pengambilan sampel yang terbuka untuk siapapun yang ingin berpartisipasi dalam penelitian, teknik ini memberikan kebebasan kepada individu untuk memutuskan keikutsertaannya sebagai responden dalam penelitian. Untuk mengumpulkan sampel menggunakan teknik tersebut peneliti akan menyebarkan link penelitian melalui media sosial (Line, Whats App, Instagram).

\section{Pengukuran}

Penelitian ini adalah penelitian kuantitatif dengan metode survei, variabel pada penelitian ini adalah smartphone addiction. Pada penelitian ini peneliti menggunakan skala sebagai metode pengumpulan data. Instrumen penelitian yang digunakan dalam penelitian ini adalah Smartphone Addiction Scale Short Version (SAS-SV) yang dikembangkan oleh Kwon, dkk (2013b) yang berjumlah 10 aitem, validitas yang digunakan adalah validitas konkuren dengan nilai reliabilitas sebesar 0.910 yang disusun berdasarkan lima dimensi, yaitu: daily- life disturbance, withdrawal, cyberspaceoriented relationship, overuse, dan tolerance. Seluruh aitem Smartphone Addiction Scale Short Version (SAS-SV) bersifat favorable. Penilaian skala menggunakan model likert yang terdiri dari 6 pilihan jawaban, yaitu sangat tidak setuju, tidak setuju, sedikit tidak setuju, sedikit setuju, setuju, dan sangat setuju. Pemberian skor terhadap jawaban pada skala dimulai dengan nilai 1 untuk pilihan "sangat tidak setuju", 2 "tidak setuju", 3 "sedikit tidak setuju", 4 "sedikit setuju", 5 "setuju", dan 6 "sangat setuju". Laki-laki yang mendapatkan skor diatas 31 dan perempuan yang mendapatkan skor diatas 33 dianggap memiliki risiko lebih tinggi mengalami smartphone addiction dibandingkan dengan laki-laki yang mendapatkan skor dibawah 31 dan perempuan yang mendapatkan skor dibawah 33.

\section{Analisis Data}

Data yang didapatkan dianalisis menggunakan metode analisis statistik deskriptif, Crosstab dan Chi-Square Test for Independence dengan menggunakan program SPSS ver. 21.0 for Windows. Analisi deskriptif dilakukan untuk mengetahui tingkat smartphone addiction pada penduduk di Kota Banda Aceh, sedangkan uji Crosstab dan Chi-Square dilakukan untuk melihat faktor yang berkontribusi antara data demografi seperti jenis kelamin, usia, pendidikan terakhir, pekerjaan, jumlah smartphone yang dimiliki, lama waktu kepemilikan smartphone, rutinitas memeriksa smartphone perhari dan total waktu penggunaan smartphone perhari dengan tingkat smartphone addiction.

\section{HASIL}

Hasil analisis deskriptif tingkat smartphone addiction menunjukkan bahwa sebanyak $51.4 \%$ subjek berada pada tingkat smartphone addiction rendah dan sebanyak $48.6 \%$ subjek berada pada tingkat smartphone addiction tinggi. 
Tabel 1. Analisis Deskriptif Tingkat Smartphone Addiction

\begin{tabular}{lcc}
\hline Tingkat Smartphone Addiction & Jumlah Subjek & Persentase (\%) \\
\hline Tingkat smartphone addiction rendah & 257 & 51.4 \\
Tingkat smartphone addiction tinggi & 243 & 48.6 \\
\hline
\end{tabular}

Berdasarkan hasil analisis deskriptif dapat diketahui bahwa pada variabel usia frekuensi subjek tertinggi terdapat pada usia 22-39 tahun yang memiliki tingkat smartphone addiction rendah dan frekuensi subjek terendah terdapat pada usia 40-54 tahun yang memiliki tingkat smartphone addiction tinggi. Pada variabel jenis kelamin frekuensi subjek tertinggi terdapat pada jenis kelamin perempuan dengan tingkat smartphone addiction rendah dan frekuensi terendah terdapat pada jenis kelamin laki-laki dengan tingkat smartphone addiction rendah. Pada variabel pendidikan terakhir frekuensi subjek tertinggi terdapat pada pendidikan terakhir sebagai pelajar (SMP, SMA) dengan tingkat smartphone addiction tinggi, sedangkan frekuensi terendah terdapat pada kelompok pendidikan terakhir sebagai sarjana (S1, S2, dan S3) dengan tingkat smartphone addiction tinggi. Selanjutnya pada variabel pekerjaan, frekuensi tertinggi terdapat pada kelompok bekerja dengan tingkat smartphone addiction rendah, dan frekuensi terendah terdapat pada kelompok pelajar dengan tingkat smartphone addiction rendah.

Variabel jumlah smartphone yang dimiliki frekuensi subjek tertinggi adalah kelompok hanya memiliki satu smartphone dengan tingkat smartphone addiction tinggi dan frekuensi terendah adalah kelompok yang memiliki 2-3 smartphone dengan tingkat smartphone addiction tinggi. Pada variabel lama kepemilikan smartphone frekuensi tertinggi yaitu kelompok kepemilikan smartphone $<1$ tahun sampai 5 tahun dengan tingkat smartphone addiction tinggi dan frekuensi terendah yaitu kelompok kepemilikan smartphone lebih dari 10 tahun dengan tingkat smartphone addiction tinggi. Pada variabel total waktu pengunaan smartphone frekuensi tertinggi adalah kelompok dengan total waktu penggunaan $>6$ jam pada tingkat smartphone addiction tinggi, dan frekuensi terendah adalah kelompok dengan total waktu penggunaan $<60$ menit pada tingkat smartphone addiction tinggi. Selanjutnya, variabel rutinitas memeriksa smartphone frekuensi tertinggi adalah kelompok dengan rutinitas memeriksa smartphone $<10$ menit sekali dengan tingkat smartphone addiction tinggi dan frekuensi terendah adalah kelompok rutinitas memeriksa smartphone $>5$ jam sekali dengan tingkat smartphone addiction tinggi.

Analisis data juga dilakukan menggunakan Crosstab dan Chi Square yang dilakukan dengan menguji 8 variabel demografi untuk mengetahui adakah kontribusi antara variabel-variabel demografi dengan tingkat smartphone addiction, hasil analisis menunjukkan bahwa terdapat 5 variabel demografi yang memiliki nilai signifikansi kurang dari $0.05(p<0.050)$, yaitu usia, pendidikan terakhir, pekerjaan, total waktu penggunaan smartphone, dan rutinitas memeriksa smartphone yang artinya variabel demografi tersebut berkontribusi terhadap tingkat smartphone addiction individu. Variabel demografi lainnya seperti jenis kelamin, jumlah smartphone yang dimiliki, dan lama kepemilikan smartphone menunjukkan nilai signifikansi lebih dari $0.05 \quad(p>0.05)$ yang artinya veriabel-variabel demografi tersebut tidak berkontribusi terhadap tingkat smartphone addiction individu secara signifikan. 
Tabel 2. Analisis Deskriptif Penyebaran Frekuensi Data Demografi Tingkat Smartphone Addiction

\begin{tabular}{|c|c|c|c|c|c|}
\hline \multirow{2}{*}{ No. } & \multirow{2}{*}{$\begin{array}{l}\text { Deskripsi } \\
\text { Subjek }\end{array}$} & \multirow{2}{*}{ Kategori } & \multicolumn{2}{|c|}{ Tingkat Smartphone Addiction (n) } & \multirow{2}{*}{$\begin{array}{l}\text { Signifikansi } \\
(p)\end{array}$} \\
\hline & & & Rendah & Tinggi & \\
\hline \multirow{3}{*}{1} & \multirow{3}{*}{ Usia } & 15-21 tahun & $71(37,0 \%)$ & $121(63,0 \%)$ & $0.000^{*}$ \\
\hline & & 22-39 tahun & $138(55,0 \%)$ & $113(45,0 \%)$ & \\
\hline & & 40-54 tahun & $48(84,2 \%)$ & $9(15,8 \%)$ & \\
\hline \multirow{2}{*}{2} & \multirow{2}{*}{$\begin{array}{l}\text { Jenis } \\
\text { Kelamin }\end{array}$} & Laki-laki & $90(48,4 \%)$ & $96(51,6 \%)$ & 0.300 \\
\hline & & Perempuan & $167(53,2 \%)$ & $14746,8 \%)$ & \\
\hline \multirow{2}{*}{3} & \multirow{2}{*}{$\begin{array}{l}\text { Pendidikan } \\
\text { Terakhir }\end{array}$} & $\begin{array}{l}\text { Pelajar (SMP, } \\
\text { SMA) }\end{array}$ & $108(40,1 \%)$ & $161(59,9 \%)$ & $0.000^{*}$ \\
\hline & & Sarjana (S1,S2,S3) & $149(64,5 \%)$ & $82(35,5 \%)$ & \\
\hline \multirow{4}{*}{4} & \multirow{4}{*}{ Pekerjaan } & Pelajar & $8(16,3 \%)$ & $41(83,7 \%)$ & $0.000^{*}$ \\
\hline & & Mahasiswa & $106(47,1 \%)$ & $119(52,9 \%)$ & \\
\hline & & Bekerja & $125(64,1 \%)$ & $70(35,9 \%)$ & \\
\hline & & Tidak Bekerja & $18(58,1 \%)$ & $13(41,9 \%)$ & \\
\hline \multirow{2}{*}{5} & \multirow{2}{*}{$\begin{array}{l}\text { Jumlah } \\
\text { Smartphone }\end{array}$} & 1 Smartphone & $207(49,4 \%)$ & $210(50,4 \%)$ & 0.078 \\
\hline & & 2-3 Smartphone & $50(60,2 \%)$ & $33(39,8 \%)$ & \\
\hline \multirow{3}{*}{6} & \multirow{3}{*}{$\begin{array}{l}\text { Lama Waktu } \\
\text { Kepemilikan } \\
\text { Smartphone }\end{array}$} & $\begin{array}{l}<1 \text { Tahun }-5 \\
\text { Tahun }\end{array}$ & $158(49,8 \%)$ & $160(50,3 \%)$ & 0.021 \\
\hline & & 6-10 Tahun & $67(48,9 \%)$ & $70(51,1 \%)$ & \\
\hline & & $>10$ Tahun & $32(71,1 \%)$ & $13(28,9 \%)$ & \\
\hline \multirow{4}{*}{7} & \multirow{4}{*}{$\begin{array}{l}\text { Total Waktu } \\
\text { Penggunaan } \\
\text { Smartphone } \\
\text { Perhari }\end{array}$} & $<60$ menit & $37(82,2 \%)$ & $8(17,8 \%)$ & $0.000^{*}$ \\
\hline & & 1-3 jam & $90(60,8 \%)$ & $58(39,2 \%)$ & \\
\hline & & 3-6 jam & $77(55,0 \%)$ & $63(45,0 \%)$ & \\
\hline & & $>6$ jam & $53(31,7 \%)$ & $114(68,3 \%)$ & \\
\hline \multirow{4}{*}{8} & \multirow{4}{*}{$\begin{array}{l}\text { Rutinitas } \\
\text { Memeriksa } \\
\text { Smartphone } \\
\text { Perhari }\end{array}$} & $<10$ menit sekali & $76(43,2 \%)$ & $100(56,8 \%)$ & $0.004^{*}$ \\
\hline & & 30 menit sekali & $84(49,4 \%)$ & $86(50,6 \%)$ & \\
\hline & & 1-5 jam sekali & $68(63,0 \%)$ & $40(37,0 \%)$ & \\
\hline & & $>5$ jam dan lainnya & $29(63,0 \%)$ & $17(37,0 \%)$ & \\
\hline
\end{tabular}

${ }^{*} p<0,05$

\section{Pembahasan}

Penelitian ini bertujuan untuk mendeteksi tingkat masalah dan faktor yang berkontribusi terjadinya smartphone addiction pada penduduk di Kota Banda Aceh. Berdasarkan penelitian yang telah dilakukan didapatkan hasil bahwa tingkat smartphone addiction pada penduduk di Kota Banda Aceh tidak jauh berbeda persebarannya, yaitu sebanyak $51.4 \%$ subjek berada pada tingkat smartphone addiction rendah dan sebanyak $48.6 \%$ subjek berada pada tingkat smartphone addiction tinggi. Meskipun hasil penelitian menunjukkan jumlah persebaran yang tidak jauh berbeda, namun hasil penelitian ini menunjukkan tingkat smartphone addiction tinggi pada penduduk di Banda Aceh memiliki proporsi yang lebih tinggi dibandingkan dengan penelitian lainnya, seperti dalam penelitian yang dilakukan oleh Lee, Kim, dan Choi (2017) menunjukkan hasil sebanyak $13.5 \%$ 
dari subjek penelitian berada pada tingkat smartphone addiction tinggi dan $86.5 \%$ subjek lainnya berada pada tingkat smartphone addiction rendah. Penelitian lainnya juga dilakukan Demirci, Akgonul, dan Akpinar (2015) pada mahasiswa di Universitas Turki menunjukkan hasil sebanyak $39.8 \%$ subjek penelitian mengalami smartphone addiction, selanjutnya penelitian yang dilakukan di Lebanon menunjukkan hasil sebanyak $44.6 \%$ dari subjek penelitian mengalami smartphone addiction (Hawi \& Samaha, 2016).

Fenomena smartphone addiction dapat memberikan dampak patologis pada penggunanya. Beberapa penelitian sebelumnya menunjukkan bahwa smartphone addiction dapat menyebabkan depresi, kecemasan, dan gangguan tidur (Elhai, Dvorak, Levine, \& Hall, 2016; Alhassan, Alqadhib, Taha, Alahmari, Salam, \& Almutairi, 2018; Xie, Dong, \& Wang, 2018). Seorang individu yang mengalami depresi dapat mendorong terjadinya penggunakan smartphone secara berlebihan untuk menghindari emosi negatif depresi, namun penggunaan smartphone yang berlebihan akan membuat individu terjaga hingga larut malam sehingga menimbulkan lebih banyak depresi, cepat marah, stress dan menjadi cemas, sehingga menyebabkan smartphone addiction berkaitan erat dengan patologis (Yen, Yen, Chen, Chang, Yeh, \& Ko, 2012).

Hasilanalisis deskriptiftingkat smartphone addiction jika dilihat lebih lanjut kelompok usia 15-21 tahun menunjukkan persentase yang lebih tinggi mengalami smartphone addiction dibandingkan dengan kelompok usia lainnya, hal ini dapat terjadi karena pada usia tersebut merupakan masa dimana individu mulai mencari identitas dirinya, pada satu sisi mereka masih bergantung pada orang tua-nya, namun disisi lain mereka berusaha untuk mandiri dan membangun identitasnya sendiri sehingga pada masa ini mereka akan menggunakan aplikasi yang ada di smartphone untuk mengeksplorasi identitas, sehingga mereka sangat terikat terhadap smartphone dan menganggap smartphone perangkat penting bagi mereka (Cha \& Seo, 2018).

Penelitian lainnya yang dilakukan oleh $\mathrm{Ha}$, Chin, Park, Ryu, dan Yu (2008) dan Lee, dkk (2016) menunjukkan penyebab remaja memiliki kecenderungan kecanduan yang lebih tinggi berkaitan dengan harga diri yang rendah pada remaja. Remaja yang memiliki harga diri rendah umumnya memiliki krisis kepercayaan diri, kurangnya kontrol diri, dan akan cenderung mencari keintiman di dunia maya di mana mereka akan membangun diri yang baru, sehingga penggunaan smartphone pada usia ini dilakukan sebagai pelarian terhadap permasalahan yang dirasakan, penyelesaian masalah dilakukan dengan melakukan hal-hal yang dianggap menyenangkan dan smartphone merupakan salah satu perangkat yang menawarkan berbagai aplikasi yang dapat dijadikan pilihan ketika menghadapi masalah sehingga pada usia tersebut lebih rentan mengalami smartphone addiction (Aydin \& Sari, 2011; Chiu, 2014; Van Deursen, Bolle, Hegner, \& Kommers, 2015). Pada usia dewasa meskipun berada pada tingkat yang lebih rendah mengalami smartphone addiction, namun tetap memiliki resiko. Penyebab usia dewasa lebih rendah mengalami smartphone addiction dapat terjadi dikarenakan penggunaan smartphone pada usia dewasa hanya sebagai pilihan disela waktu senggangnya, selain itu usia dewasa juga sudah lebih matang dalam menghadapi dan menyelesaikan permasalahan yang sedang dihadapinya (Van Deursen dkk., 2015).

Pada variabel jenis kelamin frekuensi subjek tertinggi terdapat pada jenis kelamin perempuan dengan tingkat smartphone addiction rendah dan frekuensi terendah terdapat pada jenis kelamin laki-laki dengan tingkat smartphone addiction rendah. Lebih 
lanjut jika dilihat pada tingkat smartphone addiction tinggi menunjukkan hasil jika jenis kelamin laki-laki menunjukkan nilai persentase yang lebih tinggi dibandingkan dengan perempuan, hal ini dapat disebabkan karena laki-lakiakan menggunakan smartphone untuk tujuan bisnis, pemanfaatan teknologi, dan hubungan profesional. Lebih lanjut dijelaskan bahwa laki-laki kurang memiliki kontrol diri terhadap penggunaan teknologi, sedangkan pada perempuan mereka lebih mungkin untuk mengenali penggunaan smartphone mereka yang bermasalah atau penggunaan yang berlebihan, sehingga akan berusaha untuk mengurangi atau menghentikan penggunaannya lebih dari laki-laki, sehingga dibandingkan dengan perempuan laki-laki cenderung mengembangkan ketergantungan yang berlebihan pada smartphone dan mereka cenderung menjadi pengguna yang lebih bermasalah dari perempuan (Lee, Chang, Lin \& Cheng, 2014).

Pada variabel pendidikan terakhir frekuensi subjek tertinggi terdapat pada pendidikan terakhir sebagai pelajar (SMP, SMA) dengan tingkat smartphone addiction tinggi sedangkan frekuensi terendah terdapat pada kelompok pendidikan terakhir sebagai sarjana (S1, S2, dan S3) dengan tingkat smartphone addiction tinggi, sedangkan pada variabel pekerjaan, frekuensi tertinggi terdapat pada kelompok bekerja dengan tingkat smartphone addiction rendah dan frekuensi terendah terdapat pada kelompok pelajar dengan tingkat smartphone addiction rendah. Hal ini dapat terjadi karena perbedaan dalam pemanfaatan smartphone, penggunaan smartphone pada pelajar dan mahasiswa didominasi penggunaan pada saat sekolah atau belajar, mengakses internet, mengerjakan tugas, menghabiskan waktu untuk menonton video dan bermain game, sehingga membuat mereka lebih terikat dengan penggunaan smartphone dibandingkan dengan kelompok lainnya (Tamura, Nishida, Tsuji, \& Sakakibara, 2017).
Ditinjau dari variabel total waktu pengunaan smartphone frekuensi tertinggi terdapat pada kelompok dengan total waktu penggunaan lebih dari 6 jam pada tingkat smartphone addiction tinggi, sedangkan frekuensi terendah terdapat pada kelompok dengan total waktu penggunaan dibawah 60 menit pada tingkat smartphone addiction tinggi. Selanjutnya, pada variabel rutinitas memeriksa smartphone frekuensi tertinggi terdapat pada kelompok dengan rutinitas memeriksa smartphone kurang dari 10 menit sekali dengan tingkat smartphone addiction tinggi, dan frekuensi terendah terdapat pada kelompok rutinitas memeriksa smartphone lebih dari 5 jam sekali dengan tingkat smartphone addiction tinggi. Berdasarkan penelitian yang dilakukan oleh Lin, Chiang, Lin, Ko, Lee, dan Lin (2016) dan Liu, Lin, Pan dan Lin (2016) dijelaskan bahwa smartphone addiction tidak selalu berkaitan dengan lama penggunaan smartphone, namun berdasarkan penelitian lainnya juga menunjukkan bahwa individu yang lebih sering memeriksa smartphone-nya dan lebih lama pemakaiannya memiliki kecenderungan lebih tinggi mengalami smartphone addiction (Haug, Castro, Kwon, Filler, Kowatsch, \& Schaub, 2016; Lin, Lin, Lee, \& Lin, 2015).

Hasil analisis uji Chi Square yang dilakukan menunjukkan bahwa terdapat beberapa variabel demografi yang berkontribusi terhadap tingkat smartphone addiction pada individu, yaitu usia, pendidikan terakhir, pekerjaan, total waktu penggunaan smartphone perhari, dan rutinitas memeriksa smartphone perhari dengan nilai signifikansi kurang dari $0.05(p<0.05)$.

Hasil penelitian terkait usia pada penelitian ini menunjukkan nilai $p=0.000$ dengan rentang usia 15-21 tahun merupakan rentang usia yang memiliki kecenderungan smartphone addiction tertinggi, hal ini sejalan dengan penelitian sebelumnya yang pernah dilakukan oleh Kwon, dkk (2013b), dan 
Alhassan, dkk (2018) yang menunjukkan bahwa terdapat kontribusi yang signifikan antara tingkat usia dengan tingkat smartphone addiction pada seseorang, dimana individu dengan rentang usia yang lebih muda memiliki risiko smartphone addiction yang lebih tinggi dibandingkan dengan usia dewasa, karena pada usia tersebut remaja sedang berada pada tahap pencarian identitas sehingga mereka lebih sering dalam pemanfaatan smartphone dan mereka lebih rentan menerima teknologi baru daripada kelompok generasi yang lebih tua, hadirnya teknologi apabila tidak dimanfaatkan dengan semestinya dapat menyebabkan smartphone addiction.

Hasil penelitian terkait pendidikan terakhir dan pekerjaan pada penelitian ini menunjukkan nilai $p=0.000$ dengan kategori pendidikan terakhir sebagai pelajar dan pekerjaan sebagai mahasiswa merupakan kategori yang memiliki kecenderungan smartphone addiction tinggi, sejalan dengan penelitian yang pernah dilakukan oleh Kwon, dkk (2013a) yang menunjukkan hasil dimana individu dengan tingkat pendidikan yang lebih rendah dan sebagai pelajar lebih memungkinkan untuk mengalami smartphone addiction, hal ini dapat disebabkan karena perbedaan dalam pemanfaatan smartphone dan kurangnya kontrol pada diri mereka (Kim, Namkoong, Ku, \& Kim, 2008).

Hasil penelitian terkait total waktu penggunaan smartphone dalam sehari pada penelitian ini menunjukkan nilai $p=0.000$ dengan total waktu penggunaan smartphone $>6$ jam merupakan kategori yang memiliki kecenderungan smartphone addiction tinggi, hasil penelitian ini sejalan dengan penelitian yang pernah dilakukan oleh Cha dan Seo (2018), Alhazmi, Alzahrani, Baig, Salawati, dan Alkatheri (2018) dan Lukman (2018) yang menunjukkan terdapat kontribusi yang signifikan antara total waktu penggunaan smartphone terhadap tingkat smartphone addiction, lebih lanjut dijelaskan jika semakin lama waktu yang seseorang gunakan untuk mengakses smartphonen-nya maka semakin besar pula kemungkinan individu tersebut akan mengalami smartphone addiction.

Variabel rutinitas memeriksa smartphone dalam sehari pada penelitian ini menunjukkan nilai $p=0,004$ dengan rutinitas memeriksa smartphone $<10$ menit sekali merupakan kategori yang memiliki kecenderungan smartphone addiction tinggi. Hasil ini menunjukkan bahwa terdapat kontribusi yang signifikan antara rutinitas memeriksa smartphone dengan tingkat smartphone addiction, hal ini sejalan dengan penelitian yang pernah dilakukan oleh Lin, dkk (2015) dan penelitian Riani (2016) yang mununjukkan hasil bahwa rutinitas memeriksa smartphone yang semakin sering dapat menyebabkan individu menjadi ketergantungan terhadap smartphone dan mempengaruhi tingkat smartphone addiction individu.

Pada uji Chi Square variabel demografi jenis kelamin, jumlah smartphone yang dimiliki, dan lama waktu kepemilikan smartphone memiliki nilai $p>0.05$ yang artinya variabel demografi tersebut tidak berkontribusi terhadap tingkat smartphone addiction.

Pada proses pelaksanaan penelitian ini disadari masih terdapat beberapa keterbatasan dan kekurangan, yaitu pengkategorisasian hasil penelitian yang hanya melihat berdasarkan tingkat tinggi dan rendah smartphone addiction saja dan penelitian ini bersifat kuantitatif, sehingga hasil penelitian tidak dapat melihat interaksi yang lebih mendalam antara variabel demografi dengan tingkat smartphone addiction.

\section{Kesimpuln}

Penelitian ini bertujuan untuk mengidentifikasi tingkat smartphone addiction pada penduduk di Kota Banda Aceh. Hasil penelitian 
menunjukkan bahwa tingkat smartphone addiction pada subjek penelitian tidak jauh berbeda persebarannya yaitu sebanyak $51.4 \%$ subjek memiliki tingkat smartphone addiction rendah dan $48.6 \%$ subjek memiliki tingkat smartphone addiction tinggi, hal ini menunjukkan bahwa meskipun jumlah subjek yang mengalami tingkat smartphone addiction tinggi lebih sedikit jumlahnya, tetapi perbedaannya tidak terlalu jauh dengan subjek yang memiliki tingkat smartphone addiction rendah yaitu hanya $2,8 \%$, yang mana tidak menutup kemungkinan hal tersebut dapat mengakibatkan individu mengalami tingkat smartphone addiction yang lebih tinggi. Hasil analisis Chi Square juga menunjukkan terdapat beberapa variabel demografi yang berkontribusi terhadap tingkat smartphone addiction pada individu, yaitu usia, pendidikan terakhir, pekerjaan, total waktu penggunaan smartphone perhari dan rutinitas memeriksa smartphone.

\section{Daftar Pustaka}

Agusta, D. (2016). Faktor-faktor resiko kecanduan menggunakan smartphone pada siswa di SMK negeri 1 Kalasan Yogyakarta. E-Journal Bimbingan dan Konseling, 3(5), 86-96.

Alhazmi, A. A., Alzahrani, S. H., Baih, M., Salawati, M. E., \& Alkatheri, A. (2018). Prevalence and factors associated with smartphone addiction among medical students at King Abdulaziz University, Jeddah. Pac J Med Sci, 34(4), 984988. DOI: https://doi.org/10.12669/pjms. 344.15294

Alhassan, A. A., Alqadhib, E. M., Taha, N. W., Alahmari, R. A., Salam, M., \& Almutairi, A. F. (2018). The relationship between addiction to smartphone usage and depression among adults: a cross sectional study. BMC Psychiatry, 18(148), 1-8. DOI: https://doi.org/10.1186/s12888018- 1745-4

Asosiasi Penyelenggara Jasa Internet
Indonesia. (2012). Statistic Pengguna Internet Indonesia 2012. Diakses pada tanggal 13 Mei 2019 dari https://www. slideshare.net/so3p/apjii-statistik-penggunainternet-indonesia- 2012

Aydin, B., \& Sari, S. V. (2011). Internetaddiction among adolescents: the role of selfesteem. Procedia Social and Behavioral Sciences, 15, 3500-3505. DOI: https:// doi.org/10/1016/j/sbspro.2011.04.325.

Bhattacharyya, R. (2017). Addiction to modern gadgets and technologies across generation. Eastern Journal of Psychiatry, 18(2).

Bian, M., \& Leung, L. (2014). Linking loneliness, shyness and smartphone addiction symptom, and patterns of smartphone use to social capital. Media Asia, 42(2). DOI: $10.1177 / 0894439314528779$

Boumosleh, J. M., \& Jaalouk, D. (2017). Depression, anxiety, and smartphone addiction in university students - A cross sectional study. PLOS ONE. DOI:

https://doi.org/10.1371/journal.pone.0182239

Cha, S-S., \& Seo, B-K. (2018). Smartphone use and smartphone addiction in middle school students in Korea: Prevalence, social networking service, and game use. Health PsychologyOpen, 1-15.DOI https:// doi.org/10.1177/205510291875504

Chiu, S-I. (2014). The relationship between life stress and smartphone addiction on Taiwanese university student: A meditation model of learning self-efficacy and social efficacy. Computers in Human Behavior, 34, 49-57. DOI: http://dx.doi. org/10.1016/j.chb.2014.01.024

Demirci, K., Akgonul, M., \& Akpinar, A. (2015). Relationship of smartphone use severity with sleep quality, depression and anxiety in University students. Journal of Behavioral Addiction, 4(2), 85-92. DOI: 10.1556/2006.4.2015.010.

Elhai, J. D., Dvorak, R. D., Levine, J. C., \& Hall, B. J. (2016). Problematic smartphone use: A conceptual overview 
and systematic review of relations with anxiety and depression psychopathology. Journal of Affective Disorders. DOI: http:// dx.doi.org/10.1016/j.jad.2016.08.030

Gravelly, D. (2015 September 25). Survei: Smartphone kalahkan perhatian orang tua pada anak. Techno.id.Diakses pada 16 April 2019 dari https://www.techno.id/ tech-news/survei-smartphone-kalahkanperhatian-orang-tua-pada-anak-1509254. html

Ha, J. H., Chin, B., Park, D.-H., Ryu, S.-H., \& Yu, J. (2008). Characteristics of excessive cellular phone use in Korean adolescents. Cyber Psychology \& Behavior, 11, 783784.

Haug, S., Castro, R. P., Kwon, M., Filler, S., Kowatsch, T., \& Schaub, M. P. (2015). Smartphone use and smartphone addiction among young people in Switzerland. Journal of Behavioral Addictions 4(4), 299-307. DOI: 10.1556/ 2006.4.2015.037

Hawi, N. S., \& Samaha, M. (2016). To excel or not to excel: strong evidence on the adverse effect of smartphone addiction on academic performance. Computer \& Education, 98, 81-89.

Hernanda, Y. (2017). Hubungan Lama Penggunaan Smartphone dengan Kesehatan Mental Remaja di SMK Negeri 5 Padang Tahun 2017. Skripsi. Diakses dari http://scholar.unand.ac.id/26583/

Hope, D. (2010, March 8). iPhone addictive, Survey reveals. Live Science. Diakses pada tanggal 27 Maret 2019 dari https:// www.livescience.com/6175-iphone-addictivesurvey-reveals.html

Ithnain, N., Ghazali, S. E., \& Jaafar, N. (2018). Relationship between smartphone addiction with anxiety and depression among undergraduate students in Malaysia. International Journal of Health Sciences \& Research, 8(1), 163171.

Kemp, S. (2018). Digital In 2018: World's
Internet Users Pass The 4 Billion Mark. We Are Social. Diakses pada 6 oktober 2018 dari https://wearesocial.com/ blog/2018/01/global-digital-report- 2018

Kibona, L., \& Mgaya, G. (2015). Smartphones' effects on academic performance of higher learning students. Journal of Multidisciplinary Engineering Science and Technology (JMEST), 2(4), 777784.

Kim, E-J., Namkoong, K., Ku, T., \& Kim, S-J. (2008). The relationship between online game addiction and aggression, selfcontrol, and narcissistic personality traits. Europian Psychiatri, 23(3), 212-218. DOI: 10.1016/j.eurpsy.2007.10.010.

Kim, H. (2013). Exercise rehabilitation for smartphone addiction. Journal of Exercise Rehabilitation, 9(6), 500-505.

Kim, H-J., \& Kim, J-S. (2015). The relationship between smartphone use and subjective musculoskeletal symptoms and university students. Journal of Physical Therapy Science, 27(3), 575-579. DOI: 10.1589/ jpts. 27.575

Kwon, M., Lee, J-Y., Won, W-Y., Park, J-W., Min, J-A., Hanh, C., ... Kim, D-J. (2013a). Development and validation of a smartphone addiction scale (SAS). PLOS ONE, 8(2), 1-7.

Kwon, M., Kim, D-J., Cho, H., \& Yang, S. (2013b). The smartphone addiction scale: Development and validation of a short version for adolescents. PLOS ONE, 8(12), 1-7. DOI: 10.1371/journal. pone.0083558

Lee, Y-K., Chang, C-T., Lin, Y., \& Cheng Z-H. (2014). The dark side of smartphone usage: Psychological traits, compulsive behavior and technostress. Computers in Human Behavior, 31, 373-383.

Lee, H., Kim, J. W., \& Choi, T. Y. (2017). Risk factor for smartphone addiction in Korean adolescents: smartphone use patterns. J Korean Med Sci, 32, 1674-1679. DOI: https://doi.org/10.3346/ 
jkms.2017.32.10.1674

Lemola, S., Perkinson-Gloor, N., Brand, S., Dewald-Kaufman, J. F., \& Grob, A. (2014). Adolescents' electronic media use at night, sleep disturbance, depressive symptoms in the smartphone age. Journal of Youth and Adolescence, 44(2), 405418. DOI:10.1007/s10964-014-0176-X

Lin, Y-H., Chiang, C-L., Lin, P-H., Ko, C-H., Lee, Y-H., \& Lin, S-H. (2016). Proposed diagnostic criteria for smartphone addiction. PLOS ONE, 11(11), 1-11.

Lin, Y-H., Lin, Y-C., Lee, Y-H., \& Lin, P-H. (2015).Time distortion associated with smartphone addiction: Identifying smartphone addiction via a mobile application (App). Journal of Psychiatric Research, 30, 1-7. DOI:http://dx.doi.org/10.1016/j. jpsychires.2015.04.003

Liu, C-H., Lin, S-H., Pan Y-C., \& Lin, Y-H. (2016). Smartphone gaming and frequent use pattern associated with smartphone addiction. Medicine, 95(28), 1-4.

Lukman. (2018). Penggunaan dan Adiksi Smartphone Di Kalangan Mahasiswa Fakultas Kedokteran Universitas Hasanuddin Angkatan 2015 dan 2016. Skripsi. Diakses dari http://digilib.unhas.ac.id/ uploaded_files/temporary/DigitalCollection/ ZGE2MzA czYTdjODdIODYwNjA2Mzk$2 \mathrm{MjUyOA}==. \mathrm{pdf}$

Misyaroh, D. A. (2016). Hubungan Antara Loneliness dengan SmartphoneAddiction Pada Mahasiswa Universitas Negeri Di Kota Malang. Skripsi. Diakses dari http://etheses.uin-malang.ac.id/5579/ 1/12410121.pdf

Panji, A. (2014). Hasil Survei Pemakaian Internet Remaja Indonesia. Kompas. com. Diakses pada 7 Oktober 2018 dari https://tekno.kompas.com/read/ 2014/ 02/19/1623250/Hasil.Survei.Pemakaian. Internet.Remaja.Indonesia

Riani, V. F. (2016). Gambaran Ketergantungan Smartphone Terhadap Produktivitas
Kerja pada Pekerja CV. Traveline Citra Nusantara Yogyakarta. Skripsi. Diakses dari https://repository.usd. ac.id/6627/2/099114006_full.pdf

Salehan, M., \& Negahban, A. (2013). Social networking on smartphone: When mobile phone become addictive. Computers in Human Behavior, 34, 2632-2639.

Samaha, M., \& Hawi, N., S. (2016). Relationships among smartphone addiction, stress, academic performance, and satisfaction with life. Computers in Human Behavior, 57, 321-325.

Soni, R., Upadhyay, R., \& Jain, M. (2017). Prevalence of smartphone addiction, sleep quality and associated behavior problems in adolescents. Internation Journal of Research in $M$ e d i c a I Sciences, 5(2), 512-519. DOI: http://dx.doi. org/10.18203/2320-6012.ijrms20170141

Santrock, J. W. (2012). Perkembangan Masa Hidup. Jakarta: Erlangga.

Suwannahong, R. (2018). Faktor affecting the students health from using smartphones. Herald NAMSCA, 1, 680-683.

Tamura, H., Nishida, T., Tsuji, A., \& Sakakibara, H. (2017). Association between excessive use of mobile phone and insomnia and depression among Japanese adolescents. Int J Environ Res Public Health, 14(701). DOI: 10.3390/ ijerph14070701

Tangmunkongvorakul, A., Musumari, P. M., Thongpibul, K., Srithanaviboonchai, K., Techasrivichien, T., Suguimoto, S. P., ... Kihara, M. (2019).Association of excessive smartphone use with psychological wellbeing among university students in Chiang Mai, Thailand. PLOS ONE, 14(1). DOI: e0210294. http s://doi. org/10.1371/journal.pone.0210294

Tarlemba, F., Asrifuddin, A., \& Langi F. L. F. G. (2018). Hubungan tingkat stress dan smartphone addiction dengan gangguan kualitas tidur pada remaja di SMA Negeri 9 Binsus Manado. Jurnal Kesmas, 7(5). 
Van Deursen, A. J., Bolle, C. L., Hegner, S. M., \& Kommers, P. A. M., (2015). Modelling habitual and addictive smartphone behavior the role of smartphone usage types, emotional intelligence, social stress, self-regulation, age, and gender. Computers in Human Behavior, 45, 411-420. DOI:http://dx.doi.org/10.1016/j. chb.2014. 12.039

Wardani, A. S. (2016). Menilik Perkembangan Smartphone dari Masa ke Masa. Liputan6.com. Diakses pada 5 oktober 2018 dari https://www.liputan6.com/tekno/ read/2669811/menilik-perkembangan smartphone-dari-masa-ke-masa

Wijanarko, K. S. (2014). Pengaruh nilai pelanggan terhadap kepuasan serta dampaknya terhadap loyalitas menggunakan smartphone samsung galaxy series di Kota Palu. E-Jurnal Katalogis, 2(7), 34-46.

Woodall, M. (2018, December 14). Cell Phone Behavior Survey: What Do People Do on Their Phones?. Reviews.org. Diakses pada 16 April 2019 dari ht tp s: // w w w. reviews.org/trends/cell-phone-addiction/

Xie, X., Dong, Y., \&Wang,J. (2018). Sleepquality as a mediator of problematic smartphone use and clinical health symptoms. Journal of Behavioral Addictions. DOI:

10.1556/2006.7.2018.40

Yen, J-Y., Yen, C-F., Chen, C-S., Chang, Y-H., Yeh, Y-C., \& Ko, C-H. (2012). The bidirectional interactions between addiction, behaviour approach and behaviour inhibition systems among adolescents in a prospective study. Psychiatry Research, 200, 588-592. 